\title{
Correction: Age at first birth and cardiovascular risk factors in the 1958 british birth cohort
}

Lacey RE, Kumari M, Sacker A, et al. Age at first birth and cardiovascular risk factors in the 1958 British birth cohort. J Epidemiol Community Health 2017;71:691-8. doi: 10.1136/ jech-2016-208196.

There is an error in table 1- part of the age at first birth information is missing for men.

The categories for men should be:

\begin{tabular}{lc}
\hline Age at first birth (years) & N (\%) \\
\hline$<20$ & $147(3.9)$ \\
$20-24$ & $962(26.3)$ \\
$25-29$ & $1268(34.1)$ \\
$30-34$ & $744(19.7)$ \\
$>34$ & $609(16.1)$ \\
\hline
\end{tabular}

\section{(2)}

\section{OPEN ACCESS}

Open access This is an open access article distributed in accordance with the Creative Commons Attribution 4.0 Unported (CC BY 4.0) license, which permits others to copy, redistribute, remix, transform and build upon this work for any purpose, provided the original work is properly cited, a link to the licence is given, and indication of whether changes were made. See: https://creativecommons.org/licenses/by/4.0/.

(C) Author(s) (or their employer(s)) 2020. Re-use permitted under CC BY. Published by BMJ.

J Epidemiol Community Health 2020;74:104. doi:10.1136/jech-2016-208196corr1

A) Check for updates 